BULLETIN OF PNRPU. GEOLOGY. OIL \& GAS ENGINEERING \& MINING

ВЕСТНИК ПНИПУ. ГЕОЛОГИЯ. НЕФТЕГАЗОВОЕ И ГОРНОЕ ДЕЛО

ISSN 2224-9923

Volume / Toм 15 №19 2016

http://vestnik.pstu.ru/geo/

УДК 551.86

Article / Статья

(C) PNRPU / ПНИПУ, 2016

\title{
GEOCHEMISTRY OF IMPURITY ELEMENTS OF UPPER JURASSIC DEPOSITS OF KAZAN FIELDS GROUP
}

\author{
K.V. Gabova, G.G. Kravchenko
}

TomskNIPIneft JSC (72 Mira av., Tomsk, 634027, Russian Federation)

\section{ГЕОХИМИЯ ЭЛЕМЕНТОВ-ПРИМЕСЕЙ ВЕРХНЕЮРСКИХ ОТЛОЖЕНИЙ КАЗАНСКОЙ ГРУППЫ МЕСТОРОЖДЕНИЙ}

\author{
К.В. Габова, Г.Г. Кравченко \\ ОАО «ТомскНИПИнефть» (634027, Россия, г. Томск, пр. Мира, 72)
}

Received / Получена: 30.03.2016. Ассерted / Принята: 20.04.2016. Published / Опубликована: 30.06.2016

\section{Key words:}

geochemical analysis, inductively coupled plasma, rare earth elements, Kazan oil-gas-condensate field, Boltnoe oil field, spectrum, impurity elements, normalization, standard.

\begin{abstract}
Both sandstones and fine-grain clastic debris have integrated information about factors controlling its formation processes. This information is contained in litho-geochemical characteristics. Obtained information complement and specify results of lithologic research carried by conventional methods.

The subject of the research are deposits of Kazan oil-gas-condensate field and Boltnoe oil field that are located in Parabel territory of Tomsk region. In terms of structure Kazan and Bolotnoe fields are dedicated to dome uplifts of the same names and located in south-east part of Niurolsk depression within the border of $2^{\text {nd }}$ class positive structure Kalgachskii Mesozoic uplift. Geological structure of the field is formed by metamorphosed basement rocks and siliciclastic deposits of different composition of Mesozoic-Cenozoic platform mantle. Productive deposits of Upper Jurassic are the field of interest. Upper series of Jurassic deposits on studied area is presented by Vasiugan, Georgiev and Bazhenov formations that are drilled and characterized in details by core.

Obtained data proved the rule of change of rare earth elements composition between different conditions of marginalmarine line and showed tendency of some elements to grow and decrease of other going out from margin. Sedimentary rocks of south-east part of Niurolsk depression are differentiated in geochemical and mineral-petrographical compositions. Both are presented by wide range of variety. With use of obtained geochemical data and evaluation of indicators determined environments of sedimentation are proved. Fundamental parameters of sedimentary rocks such as composition and proximity of a source, salinity and paleoclimates are determined.
\end{abstract}

Ключевые слова:

геохимический анализ, индуктивно-связанная плазма, редкоземельные элементы, Казанское нефтегазоконденсатное месторождение, Болтное нефтяное месторождение, спектр, элементы-примеси, нормализация, стандарт.
Как песчаники, так и тонкозернистые обломочные породы в своих литогеохимических характеристиках несут интегральную информацию о ряде факторов, контролирующих процессы их формирования. Полученные таким образом сведения существенно дополняют и детализируют результаты литологических исследований, выполненных традиционными методами.

Объектом исследования были выбраны отложения Казанского нефтегазоконденсатного и Болтного нефтяного месторождений, расположенных в Парабельском районе Томской области. В структурном отношении Казанское и Болтное месторождения приурочены к одноимённым куполовидным поднятиям, расположенным в юговосточной части Нюрольской впадины в пределах положительной структуры второго порядка - Калгачского мезовыступа. В геологическом строении месторождения принимают участие метаморфизованные породы фундамента и терригенные отложения различного состава мезозойско-кайнозойского платформенного чехла, среди которых наибольший интерес вызывают продуктивные отложения верхней юры. Верхний отдел юрских отложений на исследуемых площадях представлен васюганской, георгиевской и баженовской свитами, которые вскрыты бурением и детально охарактеризованы керном.

Полученные в результате проведенного исследования данные подтвердили закономерность изменения содержания редкоземельных элементов между различными обстановками в прибрежно-морской полосе и показали зависимость роста одних редкоземельных элементов и сокращения других по мере удаленности от побережья. Осадочные породы, вскрытые керном юго-восточной части Нюрольской впадины, различаются как по геохимическому, так и по минералого-петрографическому составу, и те, и другие представлены широким спектром разновидностей. С помощью полученных геохимических данных и оценки индикаторов были подтверждены выделенные ранее обстановки осадконакопления и выполнено определение фундаментальных показателей для осадочных пород - состав и удаленность источника сноса, солёность, палеоклиматические условия.

Ksenia V. Gabova - Junior Researcher (mob. tel.: +007 382261 19 65, e-mail: GabovaKV@ nipineft.tomsk.ru). The contact person for correspondence. Grigorii G. Kravchenko - PhD in Geological and Mineralogical Sciences, Head of sedimentological laboratory of the Department of Laboratory Research (mob. tel.: +007 382261 19 65, e-mail: KravchenkoGG@ nipineft.tomsk.ru).

Габова Ксения Валерьевна - младший научный сотрудник (моб. тел.: +007 382261 19 65, e-mail: GabovaKV@nipineft.tomsk.ru). Контактное лицо для переписки. Кравченко Григорий Геннадьевич - кандидат геолого-минералогических наук, заведующий лабораторией седиментологии Департамента лабораторных исследований (моб. тел.: +007 382261 19 65, e-mail: KravchenkoGG@nipineft.tomsk.ru). 


\section{Introduction}

Rare earth elements (REE) attract attention of geologists and geochemists during siliciclastic formation. They are used to overcome several geological challenges, in particular for paleostructures.

In this paper authors used methodology that is applied by a team of researchers from Voronezh State University and scientists from Zavaritsky Institute of Geology and Geochemistry of the Ural Branch of the Russian Academy of Sciences led by A.V. Maslov.

One of the methods of composition analysis of REE is mass spectrometry with inductively coupled plasma (ICP-MS) that has an advantage of determination of each element composition in the rock. That allows using obtained data to model facial conditions of formed sediments [1-7].

Kazan oil-gas-condensate field and Bolotnoe oil field located in Parabel territory of Tomsk region were selected as research subjects. In terms of structure Kazan and Bolotnoe fields are dedicated to dome uplifts of the same names and located in south-east part of Niurolsk depression within the border of Kalgachsky Mesozoic uplift that represent $2^{\text {nd }}$ class positive structure elongated north-west [8]. Geological structure of the field is formed by metamorphosed basement rocks and siliciclastic deposits of different composition of Mesozoic-Cenozoic platform mantle. Productive deposits of Upper Jurassic are the field of interest. Upper series of Jurassic deposits on studied area is presented by Vasiugan, Georgiev and Bazhenov formations that are drilled and characterized in details by core. Vasiugan formation including productive oil and gas layers of $J_{1}$ sandstone with good reservoir properties represents the most practical value. Time interval needed for Vasiugan formation form to comprises late Batonian to Late Oxfordian. According to a facies scheme of zonation [9] the region of research is located close to the border of Vasiugan and Naunak formations that leads to significant excess of mar- ginal-marine facies with respect to classical Vasiugan formation with dominant shallowmarine facies. Deposits of Vasiugan formation are transgrassively overlapped by clayish, siliceous-clayish and siliceous-carbonate rocks of Georgiev and Bazhenov formations formed mainly during pelagic genesis.

From the mudstones, siltstones and sandstones of Bazhenov, George and upper part of Vasiugan formations 52 core samples with REE determined by ICP-MS were chosen. Analysis was performed in the Centre of collective usage «Analytical center of geochemistry of natural systems» of National Research Tomsk State University. The purposes of the research were to carry geochemical typing of main litho-stratigraphic packages and determine features of its formation.

\section{Rules of change of microelement rock composition}

Results of lithofacies core analysis [10] studied sediments drilled within the Kazan and Bolotnoe fields are represented mostly by marginal-marine, less often shallow-marine and deepmarine sediments. Facies diagnosis was conducted using structural and textural features involving ichnofacies analysis and accompanied by the study of inclusions, precipitations of flora and fauna and other features.

It was found that the upper part of the productive deposits of Vasiugan formation, including reservoirs $\mathrm{J}_{1}^{1}$ and $\mathrm{J}_{1}^{2}$, was formed in an intensive hydrodynamic zone of marginal-marine conditions. The main driving forces behind the transfer and accumulation of siliciclastic material of productive formations were tidal currents and sea fluctuations in the conditions of barrier type shore. They led to formation of facies association of aeolian line of tidal shore, including facies of lagoon, tidal channels and its fan cones (high-tide deltas), wattens and marshes. Vasiugan formation is significantly overlapped by clay sediments from outer shelf of Georgiev formation which lower part (Barabin set) has specific appearance and represent evaporated cross-section. 
Studied sequence ends by pelagic sediments of Bazhenov formation.

One of the features of REE is bigger stability of even elements than odd ones. Therefore its concentration in nature is higher [3] and elements distribution curve (geochemical rock spectrum) has zigzag shape. Thus, normalization to a standard should be applied before graph building [3, 11]. As a standard, clay head sample from Russian platform (RPSC) was used.

To smooth sharp differences between concentrations a logarithmic scale was used. One of the axis was common logarithm of concentration. Thus, one of the axis represents all REE; another one represents not absolute element concentration, but a ratio of concentration of elements in the studied sample to the standard one. Those are called normalized values.

Spectrum analysis (Fig. 1) [12-14] shows differences in the distributions of REE between determined previously environments of sedimentation. During comparison of each one with the lithological characteristic general patterns of REE accumulation of each type were identified. The analysis revealed that the REE distribution depends on the hydrodynamic conditions of the basin. Spectrums of averaged values of REE are distributed on the graph with correspondence to hydrodynamic regime of sedimentation: from the most active to the most quiet (bottom up) (Fig. 1).

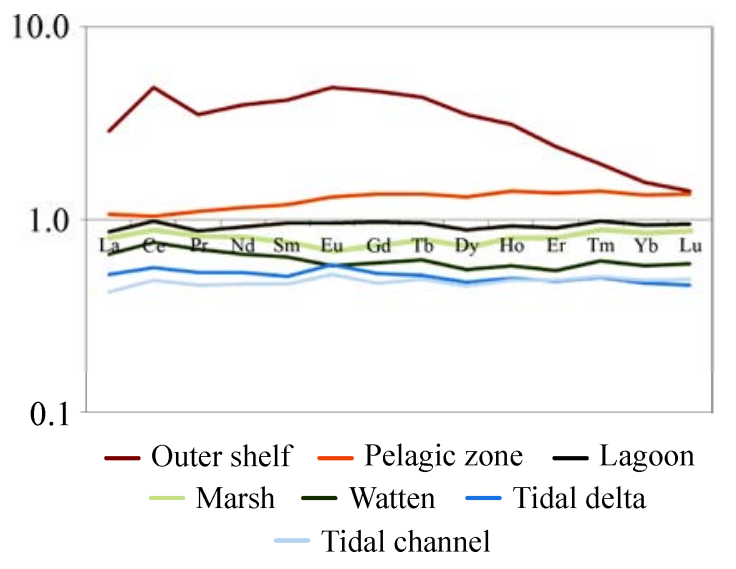

Fig. 1. Spectums of average values of REE from the rocks of south-east part of Niurolsk depression, normalized by RPSC
So, the most active in terms of hydrodynamics are sand sediments of high tide channel that have REE spectrum in the lower part of the graph. One of the important features of tidal channel sediments is discontinued character of lamination (clay slides, flasers, inerlayers of clay and aleurolite) appeared because of sharp changes of environmental dynamics - change of tidal conditions. For this reason aggradations of clay intarclasts and coalified plant detritus could appear as well as grain fluctuation and clayiness of sandstones.

After that there is a spectrum of sediments from tidal delta characterised by more quiet conditions. Sediments of tidal deltas are formed by sandstones similar to sandstones of tidal channels in composition and structure, but contain a big amount of clay interlayers, settled during quiet period.

Deposits of watten and following marsh sediments reflect less sedimentation pace in coastal part of the basin. Watten sediments in most cases are presented by thin frequent interlayers of finegrain sandstones and shale siltstones. Ratio of these rocks is determined by proximity from a coast. The more proximal from a coast to the land the less sand sediments that are grabbed by tidal wave there are and finally they disappear by the marsh zone. Marsh sediments are presented by homogeneous or fine-grain mudstones, carbonaceous siltstones, clay carbonaceous mudstones, coal, finegrain sandstones and thin (often turbidite) interlayering of mentioned rocks.

Sedimentation of lagoon mudstones and siltstones was happening even in more quite environment with rare storms that is proved by thin interlayers and lenses of light-gray fine-grain sandstone.

Finally, the most quite environment is presented by clay, siliceous-clay and siliceous-carbonate rocks of deep marine genesis of Pelagic facies.

In the rocks of evaporated cross-section of Barabin set of outer shelf facies the most REE appear to be in very high concentration. Geochemical spectrum of these sediments significantly pop-ups from the others. Sediments of outer shelf were formed in quite environment below the basis of 
storm waves with low input of detritus materials and have special geochemical conditions. Wide spread of authigenic materials such as glauconite, pyrite, phosphate rock as well as high concentration of organic matter (rostra belemnite) is an evidence of detritus material lack.

Formation of glauconite and phosphorite is associated with long influence on primary sand matter of sea water; low amount of incoming detrit-al
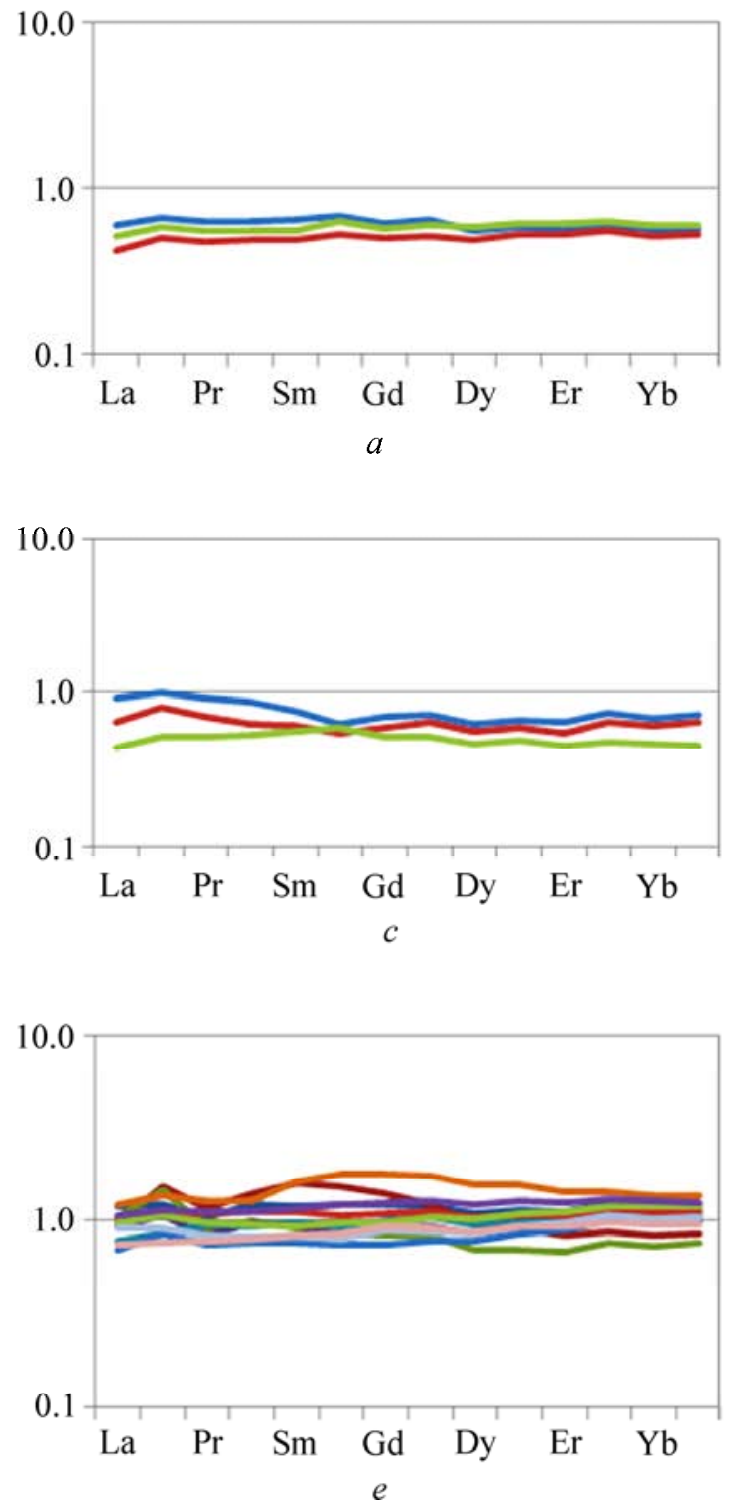

Lanthanides are similar to each other in terms of spectrum morphology. The trend of normalized values of REE to approach to RPSC values during consistent decrease of hydrodynamic level in the range tidal channel - tidal delta lagoon - watten - marsh is observed. material led to the accumulation of numerous residuals of the ancient fauna (rostra belemnite, bivalve shells and others). Evaporated cross-section that was formed this way has smaller thickness and occupies significant stratigraphic range.

To rewiew distribution of REE in details for each of the facies graphs that show concentration of REE regarding to RPSC in all samples were built (Fig. 2).
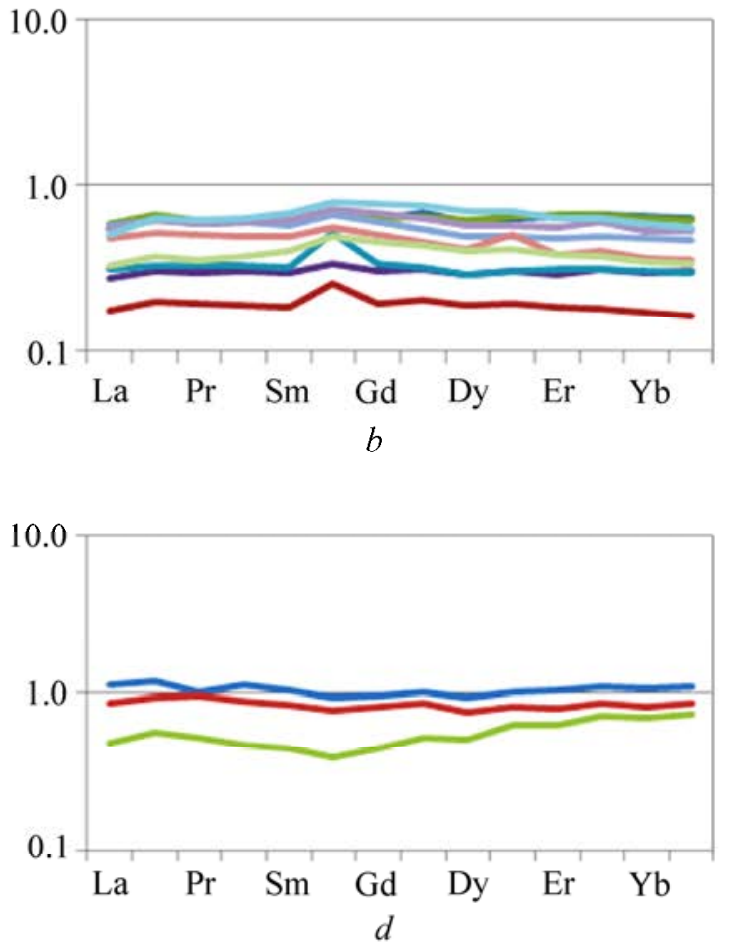

Fig. 2. Spectrums of REE (highlighted by color), normalized by RPSC and distributed in accordance with facies accessory: $a$ - tidal channel; $b$ - tidal delta; $c$ - watten; $d$ - marsh; $e$ - lagoon. Line colors on each graph represent new sample taken for research 
iments of tidal delta there is an inverse tendency. Most of the mudstones and sand-clay sediments of watten, lagoons and marsh have concentration of REE equal to RPSC (Fig. 2, $c, d, e$ ). Nevertheless, there are some differences. For instance in the sediments of watten and lagoons there is low concentration of heavy REE in comparison with light ones. Concentration of heavy REE increases in marsh sediments.

The results obtained during data interpretation proved the law of change of REE concentration in different environments of marginal-marine line and showed relationship between growth of some REE and reduction of the other going out from shore.

\section{Modeling of sedimentation conditions}

Results of geochemical analysis can also give an idea of paleographic conditions of sedimentation of detritic formations [1, 3]. Information about the content and ratio of wide spectrum of impurity elements in sandstones and fine-grain detrital rocks allow to model rock content on the paleo water collection systems, paleo geodynamic environment of initial accumulation sedimentation, to calculate abundance of elements in Earth's crust and other numerical parameters of sedimentation genesis. The ratio of impurity elements of studied samples is presented in table.

General geochemical indicator of paleogeographical conditions of the accumulation of various sediments is usually considered as $\mathrm{Ce}$ anomaly $\mathrm{Ce} / \mathrm{Ce}^{*}$ [15]. It is known that the main body of REE is delivered to final basins through rivers as a suspension. In the central areas of large sea and ocean basins Ce is oxidized and becomes soluble, that leads to appearance of negative cerium anomaly in seawater (values of $\mathrm{Ce} / \mathrm{Ce}^{*}<1$ ).

Ratio $\mathrm{Ce} / \mathrm{Ce}^{*}$ in studied samples (see table) shows margin-continental environmental sedimentational conditions. In more deep water (Pelagic) sediments the value of ration is characterized by negative Ce anomaly (0.86). At the same time ratio $\mathrm{Ce} / \mathrm{Ce}{ }^{*}>1$ in coastal-marine and shallow-marine sediments.

The ratio of impurity elements in the sediments of studied region

\begin{tabular}{|c|c|c|c|c|c|c|c|c|c|}
\hline \multirow{2}{*}{$\begin{array}{l}\text { Depositional } \\
\text { environment }\end{array}$} & \multirow{2}{*}{ Facies } & \multirow{2}{*}{$\begin{array}{l}\text { Number } \\
\text { of samples }\end{array}$} & \multirow{2}{*}{ Formation } & \multicolumn{6}{|c|}{ Average value of impurity elements ratio } \\
\hline & & & & $\mathrm{Ce} / \mathrm{Ce} *$ & $\mathrm{Ce} / \mathrm{Y}$ & $\mathrm{Ti} / \mathrm{Zr}$ & $\mathrm{Sr} / \mathrm{Ba}$ & $\mathrm{Eu} / \mathrm{Eu}^{*}$ & $\mathrm{La} / \mathrm{Yb}$ \\
\hline Deep water-marine & Pelagic region & 7 & Bazhenov & 0.86 & 7.28 & 0.79 & 0.66 & 1.03 & 0.96 \\
\hline Shallow-marine & $\begin{array}{l}\text { Outer shelf (evaporated } \\
\text { cross-section) }\end{array}$ & 3 & Georgiev & 1.52 & 11.02 & 0.80 & 0.17 & 1.10 & 1.85 \\
\hline \multirow{5}{*}{ Coastal-marine } & Lagoon & \multirow{5}{*}{42} & \multirow{5}{*}{ Vasiugan } & 1.12 & 8.97 & 1.44 & 0.61 & 1.06 & 1.41 \\
\hline & Marsh & & & 1.08 & 9.48 & 0.92 & 0.40 & 0.92 & 1.06 \\
\hline & Watten & & & 1.12 & 10.77 & 1.21 & 0.34 & 0.95 & 1.35 \\
\hline & Tidal delta & & & 1.07 & 9.52 & 1.14 & 0.38 & 1.17 & 1.63 \\
\hline & Tidal channel & & & 1.10 & 8.45 & 1.15 & 0.42 & 1.15 & 1.03 \\
\hline
\end{tabular}

A.V. Maslov also uses other ratios of REE-modeling of sedimentary environments. It is based on the fact that RRE are slightly soluble in water and, therefore, move from the region of erosion in the area of sedimentation without any loss.

The use of $\mathrm{Sr} / \mathrm{Ba}$ ratio as an indicator of paleo salinity is based on the considerations [1-3, 16]. It is known that under intense chemical weathering $\mathrm{Ba}$ and Sr migrate until enter to marine water together. In coastal water Ba quickly binds with $\mathrm{SO}_{4}^{2-}$ and precipitate. $\mathrm{Sr}$ is not sedimented on the coastal basin part and migrate to more proximal areas. Consequently, in terms of $\mathrm{Sr} / \mathrm{Ba}$ ration in the sediments of the same age it is possible to see a transition between fresh to marine sediments.

The highest value of $\mathrm{Sr} / \mathrm{Ba}$ ratio is recorded in the sediments of lagoon and Pelagic region and equals to 0.61 and 0.66 respectively (see Table). These facias have normal salinity but are most salt in respect to oters. Sediments of tidal channel (0.42) and tidal delta (0.38) have similar values, probably due to common sedimentation conditions. At the same time salinity of sediments of watten and marsh is the lowest values (0.34 and 0.40 respectively), 
probably due to its small distance from continantial part and regular desaltation of marine water. Barabin set of facias is characterized by the smaller value of $\mathrm{Sr} / \mathrm{Ba}$ ratio (0.17). That indicates freshwater sedimentation but contradict common understanding of set formation during fast transgrations and the fact that the set contains features of shallow and Pelagic sediments. This fact is of great interest and requires further research for its explanation.

In order to assess distance of clastic material transportation the ratio $\mathrm{Ti} / \mathrm{Zr}$ is often used. This parameter reflect better preservation of zircons in comparison with minerals that contain titanium during long-lasting transportation or multiple resedimentation of clastic matter [3]. Thus, rocks that are formed near to ablation source have higher ratio compared to rocks which composition contain destruction material of the same ablation source, but are transported to higher distance. This is confirmed by data obtained during recalculation of normalized values of Bazhenov, Georgiev and Vasiugan formations (see Table). It was proved that in deep water-marine sediments of Pelagic region (0.79) and shallowmarine of outer shelf $(0.80)$ the ratio $\mathrm{Ti} / \mathrm{Zr}$ is lower compared to coastal-marine genesis (0.92-1.44).

Based on the research of Iu.A. Balashov and A.B. Ronov with co-authors, climate can be indicated geochemically by the most interesting ratio $\mathrm{Ce} / \mathrm{Y}$ [17-20]. As it is known, there is no differentiation of REE in the arid climate. But there is significant differentiation of REE saturation and composition in humid sedimentation. Having the idea of REE differentiation in humid climate, that is developed by Iu.A. Balashov and his colleagues, a threshold between arid and humid environments is a ratio equals to 3 . The indicator $\mathrm{Ce} / \mathrm{Y}$ is varying between 7.28 to 11.02 that is typical for humid climate sharply.

The maximum of $\mathrm{Ce} / \mathrm{Y}$ ratio (11.02) is in the bottom of Georgiev formation (Barabin set) that tells about increase of temperature during ongoing transgression. Minimum value of $\mathrm{Ce} / \mathrm{Y}$ ratio (7.28) is typical for pelagic sediments of Bazhenov formation, that settled probably in the conditions of slightly arid climate.
Calculation of europium anomaly has obtained wide application range. That represents ration of real saturation of europium to a theoretical one that was obtained by interpolation of its neibor (samarium and gadolinium) saturations normalized in accordance with RPSC. Europium anomaly (or $\mathrm{Eu} / \mathrm{Eu}^{*}$ ) is an index of composition of rock system that were washed out by paleo water drainage $[1,3]$. Despite the fact that no negative values occur during recalculation if $\mathrm{Eu} / \mathrm{Eu}^{*}$ ratio is higher than 1 then it is positive, otherwise negative. For studied samples $\mathrm{Eu} / \mathrm{Eu}^{*}$ ratio is fluctuating between 0.92 to 1.17. Minimum values are common for marsh and watten sediments (0.92 and 0.95). In case europium anomaly is relatively small ( 0.95-0.90) it can be said that there is dominance of pre-Cambrian crystalline rocks or rocks formed by juvenile material, that was not undergone significant transformation in the continental crust.

The type of $\mathrm{La} / \mathrm{Yb}$ spectrum is a measure of ratio of acidic and basic rocks in an ablation source. If the ratio $\mathrm{La} / \mathrm{Yb}$ of studied rocks is less than 1.85 then it is possible to forecast significant role in an ablation source of igneous rocks of basic composition. Wherein for Pelagic sediments this parameter is minimal (0.96), but in coastal-marine sediments it raises to 1.03-1.63.

\section{Conclusion}

The results obtained during the study indicate that core of sedimentary rocks differ in geochemical, mineralogical and petrographic composition. Both are presented in a wide range of varieties.

Clear europium anomaly is observed in almost all studied types. An average value of $\mathrm{La} / \mathrm{Yb}$ (less that 4) proposes base composition for igneous rocks in the areas of supply. One of geochemical climate indicator is a $\mathrm{Ce} / \mathrm{Y}$ ratio. In this article ratios equal to more then 3 are common. Therefore, the type of sedimentation genesis is humid. Ratio $\mathrm{Ti} / \mathrm{Zr}$ was used to estimate distance of clastic matter transportation. It is proved that in the deep water-marine Pelagic sediments ratio $\mathrm{Ti} / \mathrm{Zr}$ is lower than in coastal-marine genesis. The value of $\mathrm{Sr} / \mathrm{Ba}$ emphasizes mainly significant salinity of the sedimentation 
basin. The only exceptions are deposits of watten and marsh where salinity is slightly lower. The ratio of $\mathrm{Ce} / \mathrm{Ce} *$ in the samples at the interval of $0.86-1.52$ indicates environment of margin-continental sedimentation regime. Thus, lithochemical data of impurity elements may be used to confirm previously selected depositional environments. It should be noted that during interpretation of the results espe- cial geochemical appearance of Barabin set of Georgiev formation was determined. That is explained by specific for condensate cross-section geochemical conditions.

The information obtained significantly complement and specify results of lithological studies, performed by conventional methods on the territory of Kazan and Bolotnoe fields.

\section{References}

1. Iudovich Ia.E., Ketris M.P. Geokhimicheskie indikatory litogeneza (litologicheskaia geokhimiia) [Geochemical indicators of Lithogenesis (lithological geochemistry)]. Syktyvkar: Geoprint, 2011. 742 p.

2. Iudovich Ia.E., Ketpic M.P. Osnovy litokhimii [Fundamental lithochemistry]. Saint-Petersburg: Nauka, 2000. 479 p.

3. Maslov A.V. Osadochnye porody: metody izucheniia i interpretatsii poluchennykh dannykh: uchebnoe posobie [Sedimentary rocks: methods of study and interpretation of obtained data: study manual]. Ekaterinburg: Izdatel'stvo UGGU, 2005. 289 p.

4. Iudovich Ia.E. Regional'naia geokhimiia osadochnykh tolshch [Regional geochemistry of sedimentary strata]. Leningrad: Nauka, 1981. $276 \mathrm{p}$.

5. Iudovich Ia.E., Puchkov V.N. Geokhimicheskaia diagnostika glubokovodnykh osadochnykh porod [Geochemical diagnosis of deep-sea sedimentary rocks]. Geokhimiia, 1980, no.3, pp.430-449.

6. Yudovich Ya.E. Coal inclusions in sedimentary rocks: a geochemical phenomenon. A review. Int. J. Coal. Geol., 2003, vol.56, 3-4, pp.203-222. DOI: 10.1016/j.coal.2003.08.002.

7. Yudovich Ya.E. Notes on the marginal enrichment of Germanium in coal beds. Int. J. Coal. Geol., 2003, vol.56, 3-4, pp. 223-232. DOI: 10.1016/j.coal.2003.08.003.

8. Zapivalov N.P., Min'ko V.A. Geologicheskoe stroenie Kazanskogo gazokondensatnogo mestorozhdeniia [Geological structure of Kazan oil-gas condensate field]. Neft' i gaz Tiumeni: trudy ZapSibNIGNI. Tiumen', 1970, vol.6, pp.39-43.

9. Resheniia 6 Mezhvedomstvennogo stratigraficheskogo soveshchaniia po rassmotreniiu i priniatiiu utochnennykh stratigraficheskikh skhem mezozoiskikh otlozhenii Zapadnoi Sibiri. Novosibirsk, 2003 g. [Decisions of the $6^{\text {th }}$ Interdepartmental Stratigraphic Meeting on the consideration and adoption of revised stratigraphic schemes of Mesozoic deposits of Western Siberia: Novosibirsk, 2003]. Novosibirsk: SNIIGGiMS, 2004. 114 p.

10. Alekseev V.P. Litologo-fatsial'nyi analiz [Lithofacial analysis]. Ekaterinburg: Izdatel'stvo UGGGA, 2003. 147 p.

11. Vinogradov A.P. Srednie soderzhaniia khimicheskikh elementov $\mathrm{v}$ glavnykh tipakh gornykh porod zemnoi kory [Average content of chemical elements in the main rock types of crustal rocks]. Geokhimiia, 1962, no.7, pp.555-571.

12. Skliarov E.V. (Ed.) Interpretatsiia geokhimicheskikh dannykh [Geochemical data interpretation]. Moscow: Intermet Inzhiniring, 2001, vol.1, 288 p.

13. Teilor S.R., Mak-Lenan S.M. Kontinental'naia kora: ee sostav i evoliutsiia [Continental crust: its composition and evolution]. Moscow, 1987. $384 \mathrm{p}$.

14. Taylor S.R., McLennan S.M. The geochemical evolution of the continental crust. Reviews in Geophysics, 1995, 33, pp.241-265. DOI: 10.1029/95RG00262.

15. Murray R.W., Buchholtzten Brink M.R., Brumsack H.J. et al. Rare earth elements in Japan Sea sediments and diagenetic behaviour of $\mathrm{Ce} / \mathrm{Ce} *$ : results from ODP Leg 127. Geochimica et 
Cosmochimica Acta, 1991, vol.55, is.9, pp.2453-2466. DOI: 10.1016/0016-7037(91)90365-C.

16. Maslov A.V., Kornilova A.Iu. K rekonstruktsii paleosolenosti sedimentatsionnogo basseina, sushchestvovavshe-go v vende v oblasti sochleneniia Russkoi platformy i Srednego Urala: predvaritel'nye dannye [To the reconstruction of paleosalinity of sedimentary basin existed at the junction of Russian platform and Middle Ural: preliminary data]. Ezhegodnik-2004. Ekaterinburg: Izdatel'stvo IGG UrO RAN, 2005. Pp.68-72.

17. Balashov Iu.A. Geokhimiia redkozemel'nykh elementov [Geochemistry of rare earth elements]. Moscow: Nauka, 1976. 268 p.

18. Balashov Iu.A., Ronov A.B., Migdisov A.A., Turanskaia N.V. Vliianie klimaticheskikh i fatsial'- nykh uslovii na razdelenie redkozemel'nykh elementov v osadochnom protsesse [Influence of climatic and facies conditions on separation of rare earth elements in the sedimentary process] Geokhimiia, 1964, no.10, pp.995-1014.

19. Ronov A.B., Balashov Iu.A., Migdisov A.A. Geokhimiia redkozemel'nykh elementov $\mathrm{v}$ osadochnom tsikle [Geochemistry of rare earth elements in the sedimentary cycle]. Geokhimiia, 1967, vol.1, pp.3-19.

20. Ronov A.B., Balashov Iu.A., Girin Iu.P. et al. Zako-nomernosti raspredeleniia redkozemel'nykh elementov $\mathrm{v}$ osa-dochnoi obolochke i $\mathrm{v}$ zemnoi kore [Laws of distribution of rare earth elements in the sedimentary shell and earth crust]. Geokhimiia, 1972, vol.12, pp.1483-1513.

\section{Список литературы}

1. Юдович Я. Э., Кетрис М. П. Геохимические индикаторы литогенеза (литологическая геохимия). - Сыктывкар: Геопринт, 2011. - 742 с.

2. Юдович Я.Э., Кетрис М.П. Основы литохимии. - СПб.: Наука, 2000. - 479 с.

3. Маслов А.В. Осадочные породы: методы изучения и интерпретации полученных данных: учебное пособие. - Екатеринбург: Изд-во УГГУ, 2005. - 289 с.

4. Юдович Я.Э. Региональная геохимия осадочных толщ. - Л.: Наука, 1981. - 276 с.

5. Юдович Я.Э., Пучков В.Н. Геохимическая диагностика глубоководных осадочных пород // Геохимия. - 1980. - № 3. - С. 430-449.

6. Yudovich Ya.E. Coal inclusions in sedimentary rocks: a geochemical phenomenon. A review // Int. J. Coal. Geol. - 2003. - Vol. 56, 3-4. P. 203-222. DOI: 10.1016/j.coal.2003.08.002.

7. Yudovich Ya.E. Notes on the marginal enrichment of Germanium in coal beds // Int. J. Coal. Geol. - 2003. - Vol. 56, 3-4. - P. 223-232. DOI: 10.1016/j.coal.2003.08.003.

8. Запивалов Н.П., Минько В.А. Геологическое строение Казанского газоконденсатного месторождения // Нефть и газ Тюмени: тр. ЗапСибНИГНИ. - Тюмень, 1970. - Вып. 6. - С. 39-43.
9. Решения 6-го Межведомственного стратиграфического совещания по рассмотрению и принятию уточнённых стратиграфических схем мезозойских отложений Западной Сибири: Новосибирск, 2003 г. - Новосибирск: СНИИГГиМС, 2004. - 114 с.

10. Алексеев В.П. Литолого-фациальный анализ. - Екатеринбург: Изд-во УГГГА, 2003. $147 \mathrm{c}$.

11. Виноградов А.П. Средние содержания химических элементов в главных типах горных пород земной коры // Геохимия. - 1962. - № 7. С. 555-571.

12. Интерпретация геохимических данных / под ред. Е.В. Склярова. - М.: Интермет Инжиниринг, 2001. - Т. І. - 288 с.

13. Тейлор С.Р., Мак-Ленан С.М. Континентальная кора: её состав и эволюция. - М., 1987. - 384 c.

14. Taylor S.R., McLennan S.M. The geochemical evolution of the continental crust // Reviews in Geophysics. - 1995. - 33. - P. 241-265. DOI: 10.1029/95RG00262.

15. Rare earth elements in Japan Sea sediments and diagenetic behaviour of $\mathrm{Ce} / \mathrm{Ce}^{*}$ : results from ODP Leg 127 / R.W. Murray, 
M.R. Buchholtzten Brink, H.J. Brumsack [et al.] // Geochimica et Cosmochimica Acta. 1991. - Vol. 55, is. 9. - P. 2453-2466. DOI: 10.1016/0016-7037(91)90365-C.

16. Маслов А.В., Корнилова А.Ю. К реконструкции палеосолености седиментационного бассейна, существовавшего в венде в области сочленения Русской платформы и Среднего Урала: предварительные данные // Ежегодник2004. - Екатеринбург: Изд-во ИГГ УрО РАН, 2005. - C. 68-72.

17. Балашов Ю.А. Геохимия редкоземельных элементов. - М.: Наука, 1976. - 268 с.
18. Влияние климатических и фациальных условий на разделение редкоземельных элементов в осадочном процессе / Ю.А. Балашов, А.Б. Ронов, А.А. Мигдисов, Н.В. Туранская // Геохимия. - 1964. - № 10. - С. 995-1014.

19. Ронов А.Б., Балашов Ю.А., Мигдисов А.А. Геохимия редкоземельных элементов в осадочном цикле // Геохимия. - 1967. - Т. І. - С. 3-19.

20. Закономерности распределения редкоземельных элементов в осадочной оболочке и в земной коре / А.Б. Ронов, Ю.А. Балашов, Ю.П. Гирин [и др.] // Геохимия. - 1972. № 12. - С. 1483-1513.

Please cite this article in English as:

Gabova K.V., Kravchenko G.G. Geochemistry of impurity elements of Upper Jurassic deposits of Kazan fields group. Bulletin of PNRPU. Geology. Oil \& Gas Engineering \& Mining, 2016, vol.15, no.19, pp.105-113. DOI: 10.15593/2224-9923/2016.19.1

Просьба ссылаться на эту статью в русскоязычных источниках следующим образом:

Габова К.В., Кравченко Г.Г. Геохимия элементов-примесей верхнеюрских отложений Казанской группы месторождений // Вестник Пермского национального исследовательского политехнического университета. Геология. Нефтегазовое и горное дело. - 2016. - Т.15, №19. - С. 105-113. DOI: 10.15593/2224-9923/2016.19.1 